\title{
PENERAPAN METODE MIND MAPPING (PETA PIKIRAN) UNTUK MENINGKATKAN KEMAMPUAN BERPIKIR KREATIF MATEMATIK SISWA SMP
}

Oleh:

\author{
Rijal Darusman \\ Guru Matematika MTs Miftahul Hasnah \\ rdarusman@ymail.com
}

\begin{abstract}
ABSTRAK
Masalah yang melatar belakangi penelitian ini adalah masih rendahnya kemampuan berpikir kreatif matematik siswa Sekolah Menengah Pertama (SMP), sehingga diperlukan metode pembelajaran untuk mengatasi masalah tersebut. Metode yang diterapkan adalah Metode Mind Mapping, dikarenakan dengan metode pembelajaran mind mapping kemampuan berpikir kreatif matematik siswa lebih baik jika dibandingkan dengan metode pembelajaran biasa.Berdasarkan latar belakang tersebut maka penelitian ini bertujuan untuk mengetahui apakah kemampuan berpikir kreatif matematik siswa yang pembelajarannya menggunakan metode mind mapping lebih baik daripada siswa yang pembelajarannya biasa. Penelitian ini merupakan kuasi eksperimen berbentuk kelompok kontrol pretes-postes, dengan perlakuan metode pembelajaran mind mapping dan pembelajaran biasa (konvensional). Pengumpulan data dalam penelitian ini berupa tes uraian sebanyak 4 soal, kemudian data skor kemampuan berpikir kreatif matematik siswa tersebut dianalisis dengan statistik deskriptif dan inferensial dengan menggunakan uji perbedaan dua rata-rata. Berdasarkan hasil analisis data diperoleh kesimpulan bahwa peningkatan kemampuan berpikir kreatif matematik siswa SMP yang pembelajarannya menggunakan metode mind mapping lebih baik daripada cara biasa.
\end{abstract}

Kata Kunci : Berpikir Kreatif Matematik, Mind Mapping

\begin{abstract}
The problem of the background of this research is still low ability to think creatively mathematical school students (SMP), so that the necessary learning methods to overcome these problems. The method applied is Mind Mapping method, because the mind mapping method of learning mathematics students' creative thinking ability is better when compared to the learning method biasa.Berdasarkan this background, this study aims to determine whether the ability of creative thinking of students learning mathematics using mind mapping better than the usual student learning. This research is a form of quasi-experimental pretest-posttest control group, the treatment methods of teaching and learning mind mapping regular (conventional). Collecting data in this study is a description of the test as much as 4 questions, then the data is the ability to think creatively math scores of students were analyzed with descriptive and inferential statistics using two different test average. Based on the results of the data analysis we concluded that the increase in the ability to think creatively mathematical junior high school students are learning to use mind mapping method is better than the usual way.
\end{abstract}

Keywords: Creative Thinking Mathematics, Mind Mapping. 


\section{PENDAHULUAN}

Salah satu bidang studi yang mendukung perkembangan ilmu pengetahuan dan teknologi adalah matematika. Oleh karena itu matematika merupakan bidang studi yang menduduki peranan penting dalam bidang pendidikan. Tujuan diberikan matematika menurut Badan Standar Nasional Pendidikan Nasional (BSNP) (Hidayat, 2009 : 1) "Pembelajaran matematika diberikan pada setiap jenjang pendidikan dasar dan menengah, bertujuan agar siswa dapat menggunakan matematika sebagai cara bernalar (berpikir logis, analitis, sistematis, kritis, dan kreatif dan kemampuan bekerja sama).

Kenyataan di lapangan menurut Munandar (2005 : 13) bahwa pendidikan di sekolah lebih berorientasi pada pengembangan inteligensi (kecerdasan) daripada pengembangan kreativitas, sedangkan keduanya sama pentingnya untuk mencapai keberhasilan dalam belajar dan dalam hidup. Oleh karena itu, pada pembelajaran matematika di sekolah hendaknya siswa dilatih untuk memiliki keterampilan berpikir kritis dan kreatif dalam memperoleh, memilih, dan mengolah informasi agar dapat bertahan dalam keadaan yang selalu berubah dan kompetitif.

Pembelajaran matematika perlu diperbaiki guna mendidik para siswa sehingga mereka bisa tumbuh menjadi orang-orang yang berpikir secara mandiri dan kreatif. Usaha ini dimulai dengan pembenahan proses pembelajaran yang dilakukan guru yaitu dengan menawarkan suatu pendekatan, model, metode yang dapat meningkatkan kemampuan berpikir kreatif matematik siswa.

Salah satu solusi dari permasalahan di atas adalah pembelajaran matematika di sekolah dengan menggunakan metode mind mappping. Metode Mind Mapping dimulai dengan suatu konsep atau tema tunggal yang memiliki banyak pemikiran yang menjadi umpan kepada siswa untuk berpikir dan menghasilkan banyak gagasan mengenai suatu konsep atau tema tunggal tersebut. Sehingga membuat sebuah topik yang panjang rumit menjadi sebuah pola singkat, menarik dan gampang untuk dipahami. Dalam pembuatan mind map atau menuangan suatu gagasan ini melatih siswa untuk memiliki kemampuan orisinil. serta pengembangan dari setiap gagasangagasan menumbuhkan kemampuan elaborasi yang membangun sesuatu dari ide-ide lainnya. Setelah itu siswa menyajikan bentuk mind map yang unik dan penuh dengan warna itu di depan kelas untuk melatih siswa memahami mind map yang dibuat dia sendiri dan berlatih untuk mengungkapkan gagasan-gasannya secara lancar di depan kelas.

Rumusan masalah dari penelitian ini adalah (1) Apakah pencapaian kemampuan berpikir kreatif matematik siswa yang pembelajarannya menggunakan metode mind mapping lebih baik daripada siswa dengan pembelajaran biasa? (2) Apakah peningkatan kemampuan berpikir kreatif matematik siswa yang pembelajarannya 
menggunakan metode mind mapping lebih baik daripada siswa dengan pembelajaran biasa?

Penelitian ini bertujuan untuk mengetahui apakah pencapaian dan peningkatan kemampuan berpikir kreatif matematik siswa yang pembelajarannya menggunakan metode mind mapping lebih baik daripada siswa yang pembelajarannya biasa".

Manfaat penelitian ini diharapkan sebagai bahan referensi bagi guru, serta memberikan alternative dalam pembelajaran yang efektif untuk meningkatkan kemampuan berpikir kreatif serta kebermaknaan pembelajaran matematika. Selain itu, manfaat penelitian ini bagi siswa antara lain : a) Menarik perhatian siswa dalam kegiatan pembelajaran, b) Membantu siswa mengembangkan kemampuan berpikir tingkat tinggi, berpikir kritis dan berpikir kreatif (critical dan creative thinking) serta dapat mengaplikasikan apa yang didapat mereka dalam kehidupan sehari-hari/ nyata, serta c) Mendorong siswa berperan aktif dalam mengkonstruksi sendiri pengetahuannya dalam menyelesaikan soal-soal matematika dengan baik.

\section{STUDI LITERATUR}

\section{Berpikir Kreatif}

Krulick dan Rudnick (Nani, 2007:35) memberikan pengertian terhadap kemampuan berpikir kreatif yaitu merupakan suatu kemampuan berpikir original dan refleksif serta menghasilkan sesuatu yang kompleks termasuk mensintesiskan gagasangagasan, memunculkan ide-ide baru,menentukan efektivitas suatu gagasan,mampu membuat keputusan dan memunculkan generalisasi.

Munandar (Kuraesin, 2009:22) memberikan uraian tentang aspek berpikir kreatif sebagai dasar untuk mengukur kreativitas siswa seprti terlihat dalam Tabel 1:

Tabel 1

Indikator Kemampuan Berpikir Kreatif

\begin{tabular}{|c|c|}
\hline Pengertian & Perilaku \\
\hline Berpikir lancar(fluency) & 1. Mengajukan banyak pertanyaan \\
\hline $\begin{array}{l}\text { 1. Mencetuskan banyak gagasan, } \\
\text { jawaban, penyelesaian maslah atau } \\
\text { jawaban. } \\
\text { 2. Memberikan banyak cara atau saran } \\
\text { untuk melakukan berbagai hal. } \\
\text { 3. Selalu memikirkan lebih dari satu } \\
\text { jawaban }\end{array}$ & $\begin{array}{l}\text { 2. Menjawab dengan sejumlah } \\
\text { jawaban jika ada pertanyaan. } \\
\text { 3. Mempunyai banyak gagasan } \\
\text { mengenai suatu masalah. } \\
\text { 4. Lancar mengungkapkan gagasan- } \\
\text { gagasan } \\
\text { 5. Bekerja lebih cepat dan melakukan } \\
\text { lebih banyak daripada orang lain. } \\
\text { 6. Dapat dengan cepat melihat } \\
\text { kesalahan dan kelemahan dari suatu }\end{array}$ \\
\hline
\end{tabular}




\begin{tabular}{|c|c|}
\hline Pengertian & Perilaku \\
\hline & objek atau situasi \\
\hline $\begin{array}{l}\text { Berpikir luwes(flexibility) } \\
\text { 1. Menghasilkan gagasan, jawaban, atau } \\
\text { pertanyaan yang bervariasi. } \\
\text { 2. Dapat melihat suatu masalah dari } \\
\text { sudut pandang yang berbeda. } \\
\text { 3. Mencari banyak alternative atau arah } \\
\text { yang berbeda-beda. } \\
\text { 4. Mampu mengubah cara pendekatan } \\
\text { atau pemikiran. }\end{array}$ & $\begin{array}{l}\text { 1. Memberikan aneka ragam } \\
\text { penggunaan yang tak lazim terhadap } \\
\text { suatu objek. } \\
\text { 2. Memberikan bermacam-macam } \\
\text { penafsiran suatu gambar,cerita atau } \\
\text { masalah. } \\
\text { 3. Menerapkan suatu konsep atau asas } \\
\text { dengan cara berbeda-beda. } \\
\text { 4. Memberikan pertimbangan terhadap } \\
\text { situasi yang berbeda dari yang } \\
\text { diberikan orang lain. } \\
\text { 5. Dalam membahas/ mendiskusikan } \\
\text { suatu situasi selalu mempunyai } \\
\text { posisi yang bertentangan dengan } \\
\text { mayoritas kelompok. } \\
\text { 6. Jika diberikan suatu masalah } \\
\text { biasanya memikirkan bermacam- } \\
\text { macam un cara } \\
\text { menyelesaikannya. } \\
\text { 7. Menggabungkan hal-hal menurut } \\
\text { pembagian (kategori yang berbeda- } \\
\text { beda) } \\
\text { 8. Mampu mengubah arah berpikir } \\
\text { secara spontan }\end{array}$ \\
\hline $\begin{array}{l}\text { Berpikir orisinal(Originality) } \\
\text { 1. Mampu melahirkan ungkapan yang } \\
\text { baru dan unik. } \\
\text { 2. Memikirkan cara-cara yang tak lazim } \\
\text { untuk mengungkapkan diri. } \\
\text { 3. Mampu membuat kombinasi- } \\
\text { kombinasi yang tak lazim dari bagian- } \\
\text { bagian atau unsur-unsur. }\end{array}$ & $\begin{array}{l}\text { 1. Memikirkan maslah-masalah atau } \\
\text { hal yang tidak terpikirkan orang } \\
\text { lain. } \\
\text { 2. Mempertanyakan cara-cara yang } \\
\text { lama dan berusaha memikirkan } \\
\text { cara-cara yang baru. } \\
\text { 3. Memilih asimetri dalam } \\
\text { menggambarkan atau membuat } \\
\text { desain } \\
\text { 4. Memilih cara berpikir lain daripada } \\
\text { yang lain. } \\
\text { 5. Mencari pendekatan yang baru dari } \\
\text { yang sterotypes (klise) } \\
\text { 6. Setelah membaca atau mendengar } \\
\text { gagasan-gagasan, bekerja untuk } \\
\text { menyelasaikan yang baru. }\end{array}$ \\
\hline
\end{tabular}




\begin{tabular}{|c|c|}
\hline Pengertian & Perilaku \\
\hline & $\begin{array}{l}\text { 7. Lebih senang mensintesa daripada } \\
\text { menganalisis sesuatu. }\end{array}$ \\
\hline $\begin{array}{l}\text { Berpikir Elaboratif(Elaboration) } \\
\text { 1. Mampu memperkaya dan } \\
\text { mengembangkan suatu gagasan atau } \\
\text { produk } \\
\text { 2. Menambah atau merinci detail-detail } \\
\text { dari suatu objek, gagasan atau situasi } \\
\text { menjadi lebih menarik }\end{array}$ & $\begin{array}{l}\text { 1. Mencari arti yang lebih mendalam } \\
\text { terhadap jawaban atau pemecahan } \\
\text { masalah dengan melakukan } \\
\text { langkah-langkah yang terperinci. } \\
\text { 2. Mengembangkan atau memperkaya } \\
\text { gagasan orang lain. } \\
\text { 3. Mencoba atau menguji detail-detail } \\
\text { untuk melihat arah yang akan } \\
\text { ditempuh. } \\
\text { 4. Mempunyai rasa keindahan yang } \\
\text { kuat, sehingga tidak puas dengan } \\
\text { penampilan yang kosong atau } \\
\text { sederhana. } \\
\text { Menambah garis-garis, warna-warna } \\
\text { dan detail-detail (bagian-bagian) } \\
\text { terhadap gambarnya sendiri atau } \\
\text { gambar orang lain. }\end{array}$ \\
\hline
\end{tabular}

Berpikir kreatif matematik adalah kemampuan yang meliputi empat komponen yaitu (1) berpikir lancar (fluency) membuat berbagai ide; (2) Berpikir luwes (flexibility) menghasilkan gagasan,jawaban, atau pertanyaan yang bervariasi,dapat melihat suatu masalah dari sudut pandang berbeda;(3) Berpikir orisinal (originality) melahirkan gagasan,ungkapan yang baru dan unik; (4) elaborasi (elaboration) membangun sesuatu dari ide-ide lainnya.

\section{Pembelajaran Mind Mapping (Peta Pikiran)}

Mind Mapping atau peta pikiran adalah metode mempelajari konsep yang ditemukan oleh Tony Buzan seorang kepala Brain Foundation tahun 1970. Konsep ini didasarkan pada cara kerja otak kita menyimpan informasi atau dapat disebut sebuah teknik pencatatan yang didasarkan pada riset tentang cara otak yang sebenarnya.

Mind mapping menurut Buzan (2006 : 16) menyatakan bahwa strategi mind mapping merupakan cara yang paling mudah untuk memasukan informasi ke dalam otak dan untuk mengambil informasi dari otak. Cara ini adalah cara yang paling kreatif dan efektif dalam membuat catatan sehingga dapat dikatakan mind mapping benar-benar memetakan pikiran orang yang membuatnya

Pandley (Tapantoko,2011: 30-31) Adapun tahap-tahap pembelajaran matematika dengan menggunakan metode mind map sebagai berikut : 
a. Guru menyampaikan materi dan tujuan pembelajaran tentang materi pelajaran yang akan dipelajari,

b. Siswa mempelajari konsep tentang materi pelajaran yang dipelajari dengan bimbingan guru,

c. Setelah siswa memahami materi yang telah diterangkan oleh guru, huru mengelompokkan siswa ke dalam beberapa kelompok sesuai dengan tempat duduk yang berdekatan. Kemudian siswa dihimbau untuk membuat peta pikiran dari materi yang dipelajari,

d. Untuk mengevaluasi siswa tentang pemahaman guru menunjuk beberapa siswa untuk mempresentasikan hasil peta pikiran dengan mencatat atau menuliskan di papan tulis,

e. Dari hasil presentasi yang ditulis oleh isswa di papan tulis, guru membimbing iswa untuk membuat kesimpulan,

f. Guru memberikan soal latihan tentang materi yang telah dipelajari kepada siswa untuk dikerjakan secara individu untuk mengetahui pemahaman konsep dan kemampuan akademis siswa.

Metode pembelajaran Mind Mapping (Peta Pikiran) adalah metode pembelajaran yang dirancang untuk mengembangkan pengetahuan siswa dengan kegiatan kreatif menyusun ide-ide pokok dari sebuah konsep menjadi sebuah peta pikiran yang mudah dipahami oleh siswa.

Berikut ini adalah petunjuk atau langkah-langkah membuat peta pikiran yang dikemukakan oleh Tony Buzan (Wikipedia, 2011) :

a. Mulailah dengan menulis topik utama di tengah kertas,

b. Gunakan ilustrasi gambar, simbol-simbol, kode-kode pada keseluruhan peta pikiran,

c. Pilih kata-kata kunci pada tiap-tiap cabang yang dikembangkan,

d. Setiap kata/gambar harus berdiri sendiri pada setiap garis/cabangnya,

e. Cabang-cabang yang dibuat harus terkait dengan topik utama di tengah kertas. Garis cabang utama lebih tebal dan menjadi lebih tipis ketika semakin menjauh dari cabang utama,

f. Buat garis/cabang yang sama panjangnya dengan kata-katanya,

g. Gunakan warna-warni dalam peta pikiran paling tidak tiga warna, sesuai selera,

h. Kembangkan bentuk peta pikiran yang sesuai dengan gaya atau kreativitas masing-masing,

i. Sisakan ruang untuk penambahan tema berikutnya.

Setiap metode atau teknik pembelajaran tentunya memiliki kelebihan masingmasing. Adapun kelebihan atau manfaat menggunakan metode mind mapping menurut Tony Buzan (Tapantoko,2011:6) Metode Mind Mapping (peta pikiran) akan meningkatkan daya hafal dan motivasi belajar siswa yang kuat, serta siswa menjadi lebih kreatif. 
Menurut Sugiarto (Tapantoko, 2011:25) menerangkan bahwa Mind Map (peta pikiran) adalah eksplorasi kreatif yang dilakukan dengan oleh idividu tentang suatu konsep secara keseluruhan, dengan membentangkan subtopik-subtopik dan gagasan yang berkaitan dengan konsep tersebut dalam satu presentasi utuh pada selembar kertas, melalui penggambaran simbol, kata-kata, garisdan tanda panah.

\section{METODE PENELITIAN}

Penelitian ini merupakan penelitian eksperimen dengan populasinya adalah seluruh siswa kelas VII di Kabupaten Sukabumi dan sampelnya dipilih secara acak dua kelas dari SMP Negeri 1 Nyalindung Kab. Sukabumi. Pemilihan sampel diambil dikarenakan sampel merupakan karakteristik dari populasi.siswa kelas VII SMP Negeri 1 Nyalindung Kec. Nyalindung Kab. Sukabumi.

Untuk memperoleh data dalam penelitian ini diperlukan instrumen penelitian, instrumen dalam penelitian ini adalah seperangkat soal tes kemampuan berpikir kreatif matematik siswa Untuk mengetahui seberapa besar peningkatan kemampuan berpikir kritis matematik siswa sebelum dan setelah kegiatan pembelajaran, dilakukan analisis skor gain ternormalisasi dilakukan perhitungan gain ternormalisasi dari Hake (Hidayat, $2011: 35$ ) berikut :

$$
\mathrm{g}=\frac{\text { skor tes akhir -skor tes awal }}{\text { skor maksimum ideal -skor tes awal }}
$$

Tingkat perolehan skor gain ternormalisasi dikelompokkan kedalam tiga kategori, yaitu :

$$
\begin{aligned}
& 0,70<\quad(\mathrm{g}) \quad \text { : Tinggi } \\
& 0,30 \leq(\mathrm{g}) \leq 0,70 \quad \text { : Sedang } \\
& \text { (g) }<0,30 \quad \text { : Rendah }
\end{aligned}
$$

\section{ANALISIS DATA DAN PEMBAHASAN}

Rekapitulasi hasil penelitian kemampuan berpikir kreatif matematik siswa antara pembelajaran yang menggunakan metode pembelajran mind mapping dengan cara biasa disajikan dalam Tabel 2 berikut :

Tabel 1.2

Rekapitulasi Hasil Penelitian Kemampuan berpikir Kreatif Matematik Siswa

\begin{tabular}{|c|c|c|c|c|c|c|}
\hline & \multicolumn{3}{|c|}{ Eksperimen } & \multicolumn{3}{c|}{ Kontrol } \\
\cline { 2 - 7 } & pretest & posttest & gain & pretest & posttest & gain \\
\hline$n$ & \multicolumn{3}{|c|}{40} & & & 38 \\
\hline & 6.15 & 10.9 & 0.50 & 6.42 & 9.74 & 0.34 \\
\hline$s$ & 1.83 & 2.49 & 0.22 & 1.71 & 2.06 & 0.19 \\
\hline
\end{tabular}

Keterangan : (SMI) berpikir kreatif $=16$ 
Berdasarkan Tabel 2 dapat dikemukakan hasil penelitian kemampuan berpikir kreatif matematik siswa antara pembelajaran yang menggunakan metode pembelajaran mind mapping dengan cara biasa sebagai berikut:

1) Berdasarkan analisis data awal (pretest) perbandingan kemampuan awal siswa pada kemampuan berpikir kreatif matematik adalah rata-rata $6.15<6.42$; standar devisiasi 1.83>1.71. Hal ini menunjukkan bahwa kemampuan awal siswa pada kemampuan berpikir kreatif matematik antara kelas eksperimen dan kelas kontrol tidak terdapat perbedaan yang signifikan dan cenderung sama.

2) Berdasarkan analisis data akhir (postest) perbandingan kemampuan akhir siswa pada kemampuan berpikir kreatif matematik siswa adalah rata-rata 10.9>9.74; standar devisisasi 2.49>2.06. hal ini menunjukkan bahwa kemampuan akhir siswa pada kemampuan berpikir kreatif matematik siswa kelas eksperimen lebih baik daripada kelas kontrol.

3) Berdasarkan analisis data gain perbandingan Peningkatan kemampuan berpikir kreatif matematik siswa adalah rata-rata 0.50>0.34; standar devisiasi 0.22>0.19. Hal ini menunjukkan bahwa peningkatan kemampuan berpikir kreatif matematik siswa kelas eksperimen lebih baik daripada kelas kontrol.

Data tersebut diuji atau diolah dengan bantuan software MINITAB 16 dan SPSS 19 dengan uji Kolmogorov-smirnov dengan taraf signifikasi $5 \%$. Setelah dilakukan uji normalitas sebaran data kemampuan berpikir kreatif matematik dan peningkatannya diperoleh bahwa data berdistribusi normal. Berdasarkan temuan tersebut, maka pengujian selanjutnya mengenai kemampuan berpikir kreatif matematik dilakukan dengan uji perbedaan rata-rata (tersaji dalam Tabel 3).

Tabel 3

Rekapitulasi Hasil Uji Perbedaan Rerata Pembelajaran Mind Mapping dengan Pembelajaran Konvensional

\begin{tabular}{|c|c|c|}
\hline KEMAMPUAN & Sig. & INTERPRETASI \\
\hline $\begin{array}{c}\text { Berpikir Kreatif } \\
\text { Matematis }\end{array}$ & 0.000 & $\begin{array}{c}\text { Kemampuan berpikir kreatif matematik siswa, yang } \\
\text { pembelajarannya menggunakan mind mapping secara } \\
\text { signifikan lebih baik dari pada cara biasa pada taraf } \\
\text { signifikansi 5\% }\end{array}$ \\
\hline $\begin{array}{c}\text { Uji Gain } \\
\text { Pemampuan } \\
\text { Matematis }\end{array}$ & 0,001 & $\begin{array}{c}\text { Peningkatan kemampuan berpikir kreatif matematik siswa, } \\
\text { yang pembelajarannya menggunakan mind mapping secara } \\
\text { signifikan lebih baik dari pada cara biasa pada taraf } \\
\text { signifikansi 5\% }\end{array}$ \\
\hline
\end{tabular}

Sumber : diadopsi dari output SPSS 19

Berdasarkan hasil pengumpulan dan pengolahan data diketahui bahwa kemampuan berpikir kreatif matematik siswa antara yang pembelajarannya menggunakan metode mind mapping lebih baik daripada cara biasa. Hasil ini memberikan gambaran bahwa metode pembelajaran yang diterpkan cukup berpengaruh terhadap 
kemampuan berpikir kreatif matematik siswa. Hal ini disebabkan pembelajaran yang menggunakan metode mind mapping menuntut siswa untuk menghasilkan banyak gagasan mengenai suatu konsep yang diberikan oleh guru yang dituangkan dalam sebuah mind map, melatih siswa memiliki kemampuan orisinil karena siswa diberikan kebebasan untuk menuangkan semua ide-idenya mengenai sebuah konsep secara kreatif dalam mind map, serta pengembangan dari setiap gagasan-gagasan menumbuhkan kemampuan elaborasi yang membangun sesuatu dari ide-ide lainnya. Setelah itu siswa menyajikan bentuk mind map yang unik dan penuh dengan warna itu di depan kelas untuk melatih siswa memahami mind map yang dibuat dia sendiri dan berlatih untuk mengungkapkan gagasan-gasannya secara lancar di depan kelas.

Berdasarkan pengolahan data di atas dapat dilihat dari perubahan rata-rata tes awal dan tes akhir pada kelas eksperimen dengan perubahan nilai rata-rata tes awal dan tes akhir pada kelas kontrol pada tabel, yang memperlihatkan perubahan nilai pada kelas eksperimen jauh lebih tinggi. Ini berarti kemampuan berpikir kreatif matematik siswa yang pembelajarannya menggunakan metode mind mapping lebih baik dari cara biasa.

Adapun hasil perhitungan dengan menguji kesamaan dua rata-rata dari data berpasangan diketahui peningkatan kemampuan berpikir kreatif matematik siswa antara metode mind mapping lebih baik daripada cara biasa. Dan secara keseluruhan dari hasil proses yang telah dilakukan dapat disimpulkan bahwa peningkatan kemampuan berpikir kreatif matematik siswa SMP yang pembelajarannya menggunakan metode mind mapping lebih baik daripada cara biasa.

Perbedaan kemampuan berpikir matematik siswa bukan dihasilkan dari suatu kebetulan, melainkan disebabkan oleh hal-hal sebagai berikut:

a. Siswa SMP sebelumnya sudah pernah menerima materi dasar bangun datar sewaktu duduk di bangku kelas 6 SD, sehingga memudahkan siswa dalam proses mengkonstruksi kemampuan awal mereka dalam pembuatan mind map.

b. Penggunaan metode pembelajaran yang inovatif yaitu metode mind mapping berpengaruh besar dalam peningkatan kemampuan berpikir kreatif matematik siswa, karena pembelajaran lebih menyenangkan, pembelajaran secara mandiri semakin besar, dan siswa lebih termotivasi untuk belajar matematimaika khususnya kemampuan berpikir kreatif matematik.

Hal ini sejalan dengan hasil penelitian Fitriana (2011) Hidayat (2011), Kuraesin (2009), dan Nani (2007) yang melaporkan bahwa kemampuan berpikir kreatif matematik siswa dengan menggunakan berbagai metode pembelajran inovatif lebih baik daripada cara biasa. 


\section{KESIMPULAN}

Berdasarkan analisis data dan pembahasan, maka kesimpulan dalam makalah ini adalah:

1. Pencapaian kemampuan berpikir kreatif matematik siswa, yang pembelajarannya menggunakan mind mapping lebih baik daripada yang cara konvensional. Pencapaian siswa yang memperoleh pembelajaran menggunakan pendekatan mind mapping dan yang cara biasa, keduanya tergolong ke dalam kategori cukup.

2. Peningkatan kemampuan berpikir kreatif matematik siswa, yang pembelajarannya menggunakan mind mapping lebih baik daripada yang cara konvensional. Peningkatan siswa yang memperoleh pembelajaran menggunakan pendekatan mind mapping dan yang cara biasa, keduanya tergolong ke dalam kategori sedang.

\section{DAFTAR PUSTAKA}

Buzan, T.(2006). Mind Map untuk Meningkatkan kreativitas.Jakarta : PT. Gramedia Pustaka Utama.

Fitriana.(2012). Penerapan Model Kooperatif Dengan Mind Mapping Untuk Meningkatkan Kemampuan Berpikir Kreatif Matematika Siswa SMA: Studi Eksperimen terhadap Siswa Kelas X SMA Negeri 6 Bandung. Skripsi S1, UPI. Bandung : Tidak Dipublikasikan.

Hidayat, W.(2011). Meningkatkan Kemampuan Berpikir Kritis Dan Kreatif Matematik Siswa Melalui Pembelajaran Kooperatif Think-Talk-Write (TTW).

Tesis S2, UPI. Bandung : Tidak Dipublikasikan

Kuraesin.(2009).Meningkatkan Kemampuan Berpikir Kreatif Siswa Menggunakan Pembelajaran Dengan Metode Improve. Skripsi S1, UPI. Bandung : Tidak Dipublikasikan.

Munandar, U.(2009). Pengembangan Kreativitas Anak Berbakat.Jakarta : PT.Rineka Cipta

Nani.(2007). Pengaruh Pembelajaran Kontekstual Terhadap Kemampuan Berpikir Kritis Dan Kreatif Matematik Serta Kemandirian Belajar Siswa Sekolah.Draft Disertasi, UPI. Bandung : Tidak diterbitkan.

Tapantoko, A.A.(2011). Penggunaan Metode Mind Mapping (Peta Pikiran) untuk Meningkatkan Motivasi Belajar SIswa dalam Pembelajaran Matematika Siswa Kelas VII SMP Negeri 4 Depok. Skripsi. FMIPA UNY. Tidak diterbitkan.

Wikipedia (2011). Mind Map.[online] Tersedia :http://en.wikipedia.org/wiki/mind_map. [12 Agustus 2011]. 